\title{
Endotoxemia and circulating bacteriome in severe COVID-19 patients
}

Phatadon Sirivongrangson, $\mathrm{MD}^{1,2,3^{*}}$, Win Kulvichit, $\mathrm{MD}^{1,2,3^{*}}$, Sunchai Payungporn, $\mathrm{PhD}^{4,5}$, Trairak Pisitkun,

$\mathrm{MD}^{5,6,7}$, Ariya Chindamporn, $\mathrm{PhD}^{8}$, Sadudee Peerapornratana, $\mathrm{MD}, \mathrm{MSc}{ }^{1,2,3,9}$, Prapaporn Pisitkun, $\mathrm{MD}^{10}$,

Suwalak Chitcharoen, $\mathrm{PhD}^{4,11}$, Vorthon Sawaswong, $\mathrm{MSc}^{4,11}$, Navaporn Worasilchai, $\mathrm{PhD}^{8}$,

Sarinya Kampunya, MSc, ${ }^{5,6,7}$ Opass Putcharoen, $\mathrm{MD}^{12}$, Thammasak Thawitsri, MD ${ }^{13}$,

Nophol Leelayuwatanakul, MD ${ }^{14}$, Napplika Kongpolprom, MD, MSc ${ }^{14}$,

Vorakamol Phoophiboon, MD, MSc ${ }^{14}$, Thitiwat Sriprasart, $\mathrm{MD}^{14}$,

Rujipat Samransamruajkit, MD ${ }^{15}$, Somkanya Tungsanga, $\mathrm{MD}^{1}$, Kanitha Tiankanon, $\mathrm{MD}^{1}$, Nuttha Lumlertgul,

$$
\mathrm{MD}, \mathrm{PhD}^{1,2,3} \text {, Asada Leelahavanichkul, } \mathrm{MD}, \mathrm{PhD}^{16},
$$

Tueboon Sriphojanart, $\mathrm{MD}^{17}$, Terapong Tantawichien, $\mathrm{MD}^{12,18}$, Usa Thisyakorn, $\mathrm{MD}^{18}$, Chintana Chirathaworn,

$$
\mathrm{PhD}^{8,18} \text {, Kearkiat Praditpornsilpa, } \mathrm{MD}^{1} \text {, }
$$

Kriang Tungsanga, $\mathrm{MD}^{1}$, Somchai Eiam-Ong, $\mathrm{MD}^{1}$, Visith Sitprija, $\mathrm{MD}, \mathrm{PhD}^{19}$,

John A. Kellum, $\mathrm{MD}^{20}$, Nattachai Srisawat, $\mathrm{MD}, \mathrm{PhD}^{1,2,3,18,20,21}$

${ }^{1}$ Division of Nephrology, Department of Medicine, Faculty of Medicine, Chulalongkorn University, Bangkok,

Thailand

${ }^{2}$ Excellence Center for Critical Care Nephrology, King Chulalongkorn Memorial Hospital, Bangkok, Thailand

${ }^{3}$ Critical Care Nephrology Research Unit, Chulalongkorn University, Bangkok, Thailand

${ }^{4}$ Department of Biochemistry, Faculty of Medicine, Chulalongkorn University, Bangkok 10330, Thailand

${ }^{5}$ Center of Excellence in Systems Biology, Chulalongkorn University (CUSB), Bangkok 10330 Thailand.

${ }^{6}$ Chulalongkorn University Center of Excellence in Systems Biology, Research Affairs, Faculty of Medicine,

Chulalongkorn University, Bangkok 10330, Thailand

${ }^{7}$ Epithelial Systems Biology Laboratory, Systems Biology Center, National Heart, Lung, and Blood Institute,

National Institutes of Health, Bethesda, Maryland

${ }^{8}$ Department of Microbiology, Chulalongkorn University, Bangkok, Thailand

${ }^{9}$ Department of Laboratory Medicine, Faculty of Medicine, Chulalongkorn University, Bangkok, Thailand

${ }^{10}$ Division of Allergy Immunology and Rheumatology, Department of Medicine, Faculty of Medicine

Ramathibodi Hospital, Mahidol University, Bangkok, Thailand.

${ }^{11}$ Program in Bioinformatics and Computational Biology, Graduate School, Chulalongkorn University, Bangkok

10330, Thailand 
${ }^{12}$ Division of Infectious Diseases, Department of Medicine, Faculty of Medicine, Chulalongkorn University, Bangkok, Thailand

${ }^{13}$ Deparment of Anesthesiology, Faculty of Medicine, Chulalongkorn University, Bangkok, Thailand

${ }^{14}$ Division of Pulmonary and Critical Care, Department of Medicine, Faculty of Medicine, Chulalongkorn University, Bangkok, Thailand

${ }^{15}$ Critical Care Excellence Center, King Chulalongkorn Memorial Hospital and Department of Pediatrics, Faculty of Medicine, Chulalongkorn University, Bangkok, Thailand

${ }^{16}$ Center of Excellence in Immunology and Immune-Mediated Diseases, Department of Microbiology, Faculty of Medicine, Chulalongkorn University, Bangkok, Thailand

${ }^{17}$ Department of Medicine, Faculty of Medicine Ramathibodi Hospital, Mahidol University, Bangkok,

Thailand.

${ }^{18}$ Tropical Medicine Cluster, Chulalongkorn University, Bangkok, Thailand

${ }^{19}$ Queen Saovabha Memorial Institute, Thai Red Cross Society, Bangkok, Thailand.

${ }^{20}$ Center for Critical Care Nephrology, The CRISMA Center, Department of Critical Care Medicine, University of Pittsburgh, School of Medicine, Pittsburgh, PA, USA

${ }^{21}$ Academy of Science, Royal Society of Thailand, Bangkok, Thailand

* Equal contribution for this work

Short running head: Endotoxemia and COVID-19

Corresponding author: Nattachai Srisawat, $\mathrm{MD}, \mathrm{PhD}$

Division of Nephrology, Department of Medicine,

Faculty of Medicine, King Chulalongkorn Memorial Hospital,

Bangkok 10330, Thailand

Phone (662) - 2564000 Ext.3597

E-mail: drnattachai@yahoo.com 


\begin{abstract}
Purpose: When severe, COVID-19 shares many clinical features with bacterial sepsis. Yet, secondary bacterial infection is uncommon. However, as epithelium are injured and barrier function is lost, bacterial products entering the circulation might contribute to the pathophysiology of COVID-19.

Methods: We studied 19 adults, severely ill patients with COVID-19 infection, who were admitted to King Chulalongkorn Memorial Hospital, Bangkok, Thailand, between $13^{\text {th }}$ March and $17^{\text {th }}$ April 2020. Blood samples on day 1, 3, and 7 of enrollment were analyzed for endotoxin activity assay (EAA), $(1 \rightarrow 3)-\beta$-D-Glucan (BG), and $16 \mathrm{~S}$ rRNA gene sequencing to determine the circulating bacteriome.

Results: Of the 19 patients, 14 were in intensive care and 10 patients received mechanical ventilation. We found 8 patients with high EAA $(\geq 0.6)$ and about half of the patients had high serum BG levels which tended to be higher in later in the illness. Although only 1 patient had a positive blood culture, 18 of 19 patients were positive for $16 \mathrm{~S}$ rRNA gene amplification. Proteobacteria was the most abundant phylum. The diversity of bacterial genera was decreased overtime.
\end{abstract}

Conclusions: Bacterial DNA and toxins were discovered in virtual all severely ill COVID-19 pneumonia patients. This raises a previously unrecognized concern for significant contribution of bacterial products in the pathogenesis of this disease.

\title{
Keywords
}

COVID-19, Critically ill, Endotoxemia, Circulating bacteriome 
medRxiv preprint doi: https://doi.org/10.1101/2020.05.29.20109785; this version posted June 2, 2020. The copyright holder for this preprint

(which was not certified by peer review) is the author/funder, who has granted medRxiv a license to display the preprint in perpetuity.

All rights reserved. No reuse allowed without permission.

\section{INTRODUCTION}

While most cases coronavirus disease 2019 (COVID-19) are mild, severe COVID-19 pneumonia can occur with a mortality rate as high as 50\% [1]. It is unclear why some patients develop clinical features of sepsis/septic shock with multiple organ dysfunction [2]. The majority of bacterial cultures from severe COVID19 patients are negative, [3] and although empiric antibiotics are commonly used, [3-5] they are not recommended [6]. However, while the respiratory tract is the principle site of infection for COVID-19, the disease has been shown to involve the GI tract as well and symptoms such as diarrhea are reported in about a third of cases [7]. Enterocytes in ileum and colon express the ACE2 receptor and virus has been detected in stool. Thus, there is a possibility that bacterial translocation from the GI tract might complicate severe COVID19 disease [8].

Endotoxin, a part of the cell wall of Gram-negative bacteria, has been extensively investigated and acknowledged as one of the key triggers of lethal shock during severe sepsis and also one of the primary drivers of the cytokine storm [9-11]. Serum $(1 \rightarrow 3)$-b-D-glucan $(B G)$ has been evaluated as a potential marker of intestinal barrier dysfunction. Serum BG was tested in several mouse models of gut leakage, including dextran sulfate solution administration, endotoxin injection, and cecal ligation and puncture sepsis [12]. However, the presence of endotoxemia and serum BG in severe COVID-19 have never been examined. Not only bacterial toxin but also direct bacterial invasion might play role in severe COVID-19. Exploring circulating bacteriome in severe COVID-19 may allow us to test the presence of any bacterial invasion during critical illness.

Thus, we designed this investigation to determine whether bacterial products were present in the blood of severe COVID-19 pneumonia patients and whether their source was likely to be the gut as evidenced by serum BG. We also sought to characterize the circulating bacteriome in COVID-19 pneumonia.

\section{METHODS}

\section{Study population, setting, and data collection}

This was a prospective observational study in COVID-19 pneumonia patients admitted to King Chulalongkorn Memorial Hospital, Bangkok, Thailand, between $13^{\text {th }}$ March and $17^{\text {th }}$ April 2020. Our inclusion criteria included (1) age >18 years, (2) confirmed COVID-19 pneumonia, and (3) had leftover blood samples. The first day of enrollment was the day that patients fulfilled inclusion criteria. The study was reviewed and approved by Faculty of Medicine, Chulalongkorn University ethics committee (IRB no. 336/63). The informed 
consent was waived due to the observational nature of the study. The study was designed and conducted according to the STROBE guideline [13].

We obtained demographic data, information on clinical presentations, laboratory investigations, and radiography at the time of presentation, and during intensive care unit (ICU) admission. We collected blood samples that were left over on day 1, day 3, and day 7 after enrollment. All laboratory tests and radiologic assessments, including standard chest radiographs and chest computed tomography, were performed at the discretion of the treating physician. Endotoxin activity assay (EAA), cytokines, and serum BG were measured on day 1, 3, and 7 of enrollment. We assessed clinical outcomes on day 28 after enrollment, including mechanical ventilation, ventilator-free day, vasopressor, prone position, extracorporeal membrane oxygenation (ECMO), acute kidney injury (AKI), renal replacement therapy (RRT), and successful extubation.

\section{Study definitions}

A confirmed case of COVID-19 was defined by a positive result of a reverse-transcriptase-polymerasechain-reaction (RT-PCR) assay of a specimen collected from a nasopharyngeal swab. We defined COVID-19 pneumonia as a COVID-19 case who showed the evidence of pulmonary infiltration from chest radiography or chest computer tomography. We defined severe COVID-19 as a COVID-19 case who was admitted in ICU. Acute kidney injury was defined based on serum creatinine and urine output criteria according to the Kidney Disease Improving Global Outcome 2012 guideline [14]. We defined patient with high endotoxin by EAA $\geq 0.6$ on day 1 .

\section{Standard of care treatment}

Treating physicians performed thorough evaluations and managed COVID-19 patients with standard care including volume status assessment, hemodynamic and respiratory support according to Surviving Sepsis Campaign: Guidelines on the Management of Critically Ill Adults with Coronavirus Disease 2019 (COVID-19) [6]. Although, currently, there is no specific antiviral treatment for COVID-19, antiviral therapy was given to all patients with confirmed COVID-19 pneumonia as recommended by the Department of Medical Service,

Ministry of Public Health of Thailand. The treatment consists of a combination of (1) favipiravir, (2) lopinavir/ritonavir or darunavir, (3) hydroxychloroquine, and (4) azithromycin.

\section{Laboratory procedures}


medRxiv preprint doi: https://doi.org/10.1101/2020.05.29.20109785; this version posted June 2, 2020. The copyright holder for this preprint (which was not certified by peer review) is the author/funder, who has granted medRxiv a license to display the preprint in perpetuity. All rights reserved. No reuse allowed without permission.

\section{COVID-19 test confirmation}

COVID-19 tests were performed by qRT-PCR technique using cobas ${ }^{\circledR}$ SARS-CoV-2 qualitative test with the $\operatorname{cobas}^{\circledR} 6800$ platform (Roche Diagnostics, Indianapolis, IN). We followed the manufacturer's instructions for testing. The samples were obtained by nasopharyngeal swab and preserved in viral transport cases before sending to analysis. The qRT-PCR tests provided cycle threshold $(\mathrm{Ct})$ value for each test. These values represent the number of cycles required for the positive fluorescent signal. Therefore, the lower $\mathrm{Ct}$ values correlated with the higher viral load. The assay is designed to detect ORF1 genes and $\mathrm{N}$ genes of SARS-CoV-2. The result was considered positive when the $\mathrm{Ct}$ values of both target genes were $<40$, negative when they were both $>40$. If only one of the target genes had a $\mathrm{Ct}$ value $<40$, the tests were confirmed by another RT-PCR machine, CFX96 Touch qPCR Detection System (Bio-Rad, Hercules, CA) with detection of 3 genes (ORF1 gene, ORF3 gene, and $\mathrm{N}$ gene). All procedures were performed in a biosafety level 2 laboratory.

\section{Endotoxin activity assay}

We performed the chemiluminescent-based endotoxin activity assay (EAA; Spectral Diagnostics, Ontario, Canada) as described elsewhere [15]. This assay is based on the detection of enhanced respiratory burst activity in neutrophils following their priming by complexes of endotoxin and a specific anti-endotoxin antibody. Briefly, $40 \mu \mathrm{L}$ of whole blood were incubated with zymosan and anti-endotoxin antibody. The endotoxin activity level of $\geq 0.60$ was considered as high activity level.

$\operatorname{Serum}(1 \rightarrow 3)-b-D$-glucan $(B G)$

We analyzed serum for BG with Fungitell ${ }^{\circledR}$ assay (Associates of Cape Cod, Falmouth, MA) following manufacturer instructions. Briefly, $5 \mathrm{~mL}$ of serum was mixed with an alkaline pretreatment reagent $(0.125 \mathrm{M}$ $\mathrm{KOK} / 0.6 \mathrm{M} \mathrm{KCl}$ ) and incubated at $37^{\circ} \mathrm{C}$ for 10 minutes. One hundred microliters of the reconstituted Fungitell reagent was added to each well and the reaction monitored at A405nm-A490nm for 40 minutes. The Fungitell assay detects BG through the activation of factor $\mathrm{G}$, a protease zymogen which activates a second protease zymogen, pro-clotting enzyme, that cleaves a chromophore from a chromogenic peptide resulting in light absorbance at $405 \mathrm{~nm}$. Serum BG $>60 \mathrm{pg} / \mathrm{mL}$ was used as positive cut-off [16]. BG values at $<7.8 \mathrm{pg} / \mathrm{mL}$ and $>523.4 \mathrm{pg} / \mathrm{mL}$ were recorded as 0 and $523 \mathrm{pg} / \mathrm{mL}$, respectively.

Cytokines 
medRxiv preprint doi: https://doi.org/10.1101/2020.05.29.20109785; this version posted June 2, 2020. The copyright holder for this preprint (which was not certified by peer review) is the author/funder, who has granted medRxiv a license to display the preprint in perpetuity.

All rights reserved. No reuse allowed without permission.

We measured a panel of cytokines including Interleukin 1 beta (IL-1 $\beta$ ), Interferon alpha-2 (IFN- $\alpha 2$ ), Interferon gamma (IFN- $\gamma$ ), Tumor necrosis factor- $\alpha$ (TNF- $\alpha$ ), Monocyte chemoattractant protein-1 (MCP-1), Interleukin 6 (IL-6), Interleukin 8 (IL-8), Interleukin 10 (IL-10), Interleukin-12, p70 (IL-12 p70), Interleukin17A (IL-17A, Interleukin 18 (IL-18), Interleukin 23 (IL-23), and Interleukin 33 (IL-33) at the same time points using LEGENDplex ${ }^{\mathrm{TM}}$ Human Th Cytokine Panel (BioLegend, San Diego, CA, USA) according to manufacturer's protocol.

\section{S rDNA high-throughput sequencing}

Genomic DNA was extracted from $300 \mu 1$ of whole blood using the GenUp ${ }^{\mathrm{TM}} \mathrm{gDNA}$ kit (Biotechrabbit, Germany). The amplification of the bacterial 16S rDNA was performed in total volume $25 \mu 1$ consisting of Taq DNA Polymerase (0.5U) (Biotechrabbit, Germany), $1.5 \mathrm{mM} \mathrm{MgCl}, 0.2 \mathrm{mM}$ dNTPs, $0.2 \mathrm{mM}$ forward primer 5'- ACTCCTACGGRAGGCAGCAG-3' and 0.2 mM reverse primer 5'-

CCGTCAATTYYTTTRAGTTT-3'. The PCR product was re-amplified within V4 region of 16S rDNA by using phasing adaptor primers following from [17]. Amplified PCR products ( 430bp) were purified by using the QIAquick PCR Purification Kit (QIAGEN, Germany) and quantified by KAPA library quantification kits for Illumina platforms (Kapa Biosystems, USA). The DNA libraries were pooled at equal amount and pairedend (2x250 cycles) sequenced on an Illumina MiSeq platform with a MiSeq Reagent Kit V2 (Illumina, USA).

\section{Statistical analyses}

Raw sequencing data were demultiplexed by MiSeq reporter software (version 2.6.2.3). The FASTQ files were analyzed by QIIME2 pipeline (version 2019.7) [18]. The paired-end sequences were merged and trimmed based on quality score $(<\mathrm{Q} 30)$. Then, merged reads were deduplicated and clustered with $99 \%$ similarity by using VSEARCH [19]. UCHIME algorithm were used for filtered out the chimeric sequences [20]. The filtered reads were classified based on 16S Greengene database [21] using VSEARCH algorithm. The alpha diversity was analyzed by implemented function in QIIME2. Differential abundance analysis was conducted by Linear discriminant analysis Effect Size (LEfSe) [22]. Wilcoxon matched pairs test were analyzed using GraphPad Prism version 6.01.

Statistical comparisons for continuous and categorical data were performed using Chi-square/Fisher Exact test and Mann-Whitney U test/Kruskal-Wallis test. Data is reported as counts (percentages) for categorical and median with interquartile range for continuous data. No imputation was performed on missing 
medRxiv preprint doi: https://doi.org/10.1101/2020.05.29.20109785; this version posted June 2, 2020. The copyright holder for this preprint (which was not certified by peer review) is the author/funder, who has granted medRxiv a license to display the preprint in perpetuity.

All rights reserved. No reuse allowed without permission.

data. All statistical analyses were performed using Stata version 15.1 (STATA Corp, TX). P value of less than 0.05 was considered as statistical significance for all tests performed.

\section{RESULTS}

A total of 147 patients were recruited. Of these, 53 (34.6\%) patients were diagnosed COVID-19 pneumonia. Among patients with COVID-19 pneumonia, only 19 patients fulfilled the inclusion criteria and 13 (68.4\%) patients were admitted in the ICU (Figure 1). Male sex was predominant in our cohort. Markers of inflammations including ferritin, C-reactive protein (CRP), and IL-6 were markedly high (Table 1). We showed detailed clinical data and outcomes of 19 patients in Table 2 and Table S1.

Endotoxin activity and $B G$

Overall median (IQR) EAA on day 1, day 3, and day 7 were $0.57(0.47,0.86), 0.65(0.49,0.96)$, and $0.57(0.43,0.74)$ respectively. There were $8(42.1 \%)$ patients with day 1 EAA $\geq 0.60$ (Table 1$)$. Distributions of EAA on day 1, day 3, and day 7 are shown in Figure 2a.

Figure $2 \mathrm{~b}$ demonstrates the distributions of serum BG following day of enrollment. During 7 days of observation, 8 patients (42.1\%) had high BG levels (defined as BG $>60 \mathrm{pg} / \mathrm{mL}$ ), and 37.5\% of patients with high BG also had EAA >0.6. The level of BG increased following the day of enrollment (Figure 2b). The median BG levels were higher in patients with high EAA compared those with low EAA [day1 (25 VS 12 $\mathrm{pg} / \mathrm{mL})$, day 3 (42 vs $10 \mathrm{pg} / \mathrm{mL})$, and day 7 (75 vs $26 \mathrm{pg} / \mathrm{mL})]$.

\section{Circulating bacteriome}

Forty-nine of 50 samples (98.3\%) from 19 COVID-19 pneumonia patients had presence of bacterial DNA in serum. Rarefaction curves were shown in Figure S1. Bacterial classification revealed that the relative abundances of bacteria were different among patients and days of illness (Figure 3). Taxonomy composition phyla abundances revealed that the Proteobacteria phylum was the predominant phylum at every time point (Figure 4, S2). Interestingly, Gram-negative bacterial genera including Sphingomonas, Bradyrhizobium, Enhydrobacter, Phyllobacterium, Agrobacterium, Comamonas, Sediminibacterium, Acinetobacter, and Pseudomonas were most likely found in different days of illness (Figure 3). Biodiversity of bacteria, demonstrated by the Chao1 richness, on day 1 was significantly higher than on day 3 (Figure S3, S4). The bacterial genera including Sphingomonas and Sediminibacterium were significantly $(\mathrm{P}<0.05)$ higher on day 3 
medRxiv preprint doi: https://doi.org/10.1101/2020.05.29.20109785; this version posted June 2, 2020. The copyright holder for this preprint (which was not certified by peer review) is the author/funder, who has granted medRxiv a license to display the preprint in perpetuity.

All rights reserved. No reuse allowed without permission.

compared to day 1; whereas Comamonas, Acinetobacter, and Pseudomonas were significantly $(\mathrm{P}<0.05)$

decreased on day 3 (Figure S5).

Cytokines

A heat map of cytokine levels on day 1,3, and 7 is depicted in Figure 5. Most of COVID-19

pneumonia had elevated of cytokines. On day 1, MCP-1, IL-6, IL-8, IL-10 in COVID-19 pneumonia who were admitted in ICU were significantly higher than COVID-19 pneumonia who were not admitted in ICU [(848

$(410,1782)$ vs $285(215,300), \mathrm{P}=0.003 ; 45(16,334)$ vs $12(7,25), \mathrm{P}=0.023 ; 73(47,128)$ vs $24(20,41)$,

$\mathrm{P}=0.009 ; 23(19,56)$ vs $8(2,13), \mathrm{P}=0.022$.] (Table S1).

Clinical characteristics at baseline and outcomes

Comparing clinical features between patients with high $(\geq 0.6$ on day 1$)$ and low EAA $(<0.6$ on day 1$)$ revealed that those with high EAA had lower median age, and higher severity scores (Table 1). Patients with high EAA levels sought medical attention earlier than patients with low EAA levels [median time from onset of fever to hospital admission $[3.5(2,5)$ vs $7(5,8), \mathrm{P}=0.01]$.

Regarding clinical outcomes, patients with high EAA were more likely to develop subsequent bacterial infection within 28 days after enrollment (38\% vs 18\%). Patients with high EAA tended to need more mechanical ventilation support than the low EAA group, although the statistical significance was not attained (62.5\% vs $45.5 \%, \mathrm{P}=0.65)$. The proportion of patients requiring vasopressors, prone position, and ECMO did not differ between EAA groups (Table 2)

Twenty-eight-day outcomes are shown in Figure 6. The overall rate of AKI (any stage) in our study was $42.1 \%$. Three $(15.8 \%)$ patients required renal replacement therapy (RRT). When compared to patients with low EAA, patients with high EAA tended to have lower ventilator-free days $[23.5(15,28)$ vs $28(21.5,28)$; $\mathrm{P}=0.51]$ and successful extubation rate $(20 \%$ vs $60 \% ; \mathrm{P}=0.52)$. No patient died within 28 days after enrollment.

\section{Discussion}

In this cohort of COVID-19 pneumonia, we show that nearly $90 \%$ and $40 \%$ of patients had endotoxemia (defined as a moderate to high level of EAA), and high levels of BG, a measure of gut permeability (Figure 2). Using Next Generation Sequencing (NGS), we could also demonstrate the dominant 
medRxiv preprint doi: https://doi.org/10.1101/2020.05.29.20109785; this version posted June 2, 2020. The copyright holder for this preprint (which was not certified by peer review) is the author/funder, who has granted medRxiv a license to display the preprint in perpetuity.

All rights reserved. No reuse allowed without permission.

bacterial DNA came from Proteobacteria, a phylum of Gram-negative bacteria which includes several pathogens that can cause sepsis, (Figure 4).

In animals, high endotoxin activity in viral infection has been demonstrated to be associated with poor outcome. Inoculation of Lipopolysaccharides (LPS) in mice with influenza infection resulted in the activation of local pulmonary inflammatory responses and may lead to secondary bacterial pneumonia [23]. LPS binds with toll-like receptor 4 (TLR4) and activates transcription factors activating protein-1 (AP-1), nuclear factor kappa B (NF-kB) and interferon regulatory factor 3 (IRF3) through myeloid differentiation factor 88 (MyD88) and TIR-domain-containing adapter-inducing interferon- $\beta$ (TRIF)-dependent pathways. This leads to the induction of proinflammatory cytokines and interferons [24].

BG is a key structural polysaccharide of the cell wall of most fungi including Candida spp., and has been used in the diagnosis of invasive fungal infection $[16,25]$. Leelahavanichkul et al. reported the use of serum BG as a biomarker of gut permeability in human sepsis [12]. In our study, the increase of serum BG level later in the course of illness (Figure 2b) might reflect overgrowth of Candida spp. in the gastrointestinal tract from antibiotics exposure [26]. Intestinal Candida overgrowth alone did not increase serum BG. Hence, the detection of BG in serum implied gut-permeability defect in these patients. In addition, BG also induced proinflammatory responses through Dectin-1 signaling [12].

With NGS, a high sensitive technology, we could detect bacteria which were unable to grow using standard culture methods. From previous reports, bacterial DNA and RNA were discovered between $4 \%$ to $100 \%$ in blood of healthy individual [27-31]. Our data agree with Gosiewski et al. which showed increased abundance of proteobacteria in sepsis patients compared to the healthy population $(60.1 \%$ vs $16.4 \%)$ [32]. This raises the possibility that COVID-19 could cause sepsis like syndrome with the same dominant bacteria phylum as in sepsis patients. This phylum contains many genera of bacteria. The most predominant bacteria were Sphingomonas, Bradyrhizobium, and Enhydrobacter. Sphingomonas paucimobilis is an opportunistic pathogen that can cause hospital associated infections from environmental exposure [33]. Bradyrhizobium enterica were found in patients with colitis [34]. Enhydrobacter aerosaccus can be detected from a patient with Hemophagocytic lymphohistiocytosis (HLH) with concomitant corticosteroid use [35]. This is particularly of interest due to the growing evidence of HLH syndrome in severe COVID-19 patients [36].

Patients with COVID-19 have been found to have high levels of proinflammatory cytokines such as IL6, IL-1 $\beta$, IP10, and MCP-1 [4]. Similar findings were also reported in patients with SARS [37] and MERS-CoV 
medRxiv preprint doi: https://doi.org/10.1101/2020.05.29.20109785; this version posted June 2, 2020. The copyright holder for this preprint (which was not certified by peer review) is the author/funder, who has granted medRxiv a license to display the preprint in perpetuity.

All rights reserved. No reuse allowed without permission.

[38]. This has prompted several authors to discuss so-called "Cytokine Storm” in viral respiratory infection that is a cause of multiple organ failure. However, our results suggest that bacterial products might be another possible contributor to the cytokine storm rather than only the virus itself.

The source of bacterial toxin, and bacterial DNA in the blood of patients with COVID-19 pneumonia is unclear. It is possible that viremia results in capillary leakage syndrome similar to bacterial sepsis which causes interstitial edema and induces dysfunction of the lung and intestinal barrier which may facilitate bacterial toxin and live bacteria translocation into the circulation. These bacterial products then induce the release of proinflammatory cytokines. In our study, many patients $(47.3 \%)$ ultimately developed subsequent bacterial infection within 28 days. Hanada et al. proposed the mechanism of viral-induced susceptibility of secondary bacterial infection involving local and systemic immune response which results in alterations in respiratory and gut microbiomes and impaired pulmonary immune response [39]. However, the GI tract appears to be another target of COVID-19. Similar to respiratory tract, various cells in the GI tract also express ACE2 and TMPRSS2 which are crucial for fusion of viral particles with host cells [40, 41]. Biopsies from severe cases have revealed involvement of COVID-19 throughout the GI tract from esophagus to colon [42]. Thus, we propose that loss of gut barrier function might also contribute to the presence of bacterial toxin and bacterial DNA in the blood of patients with severe COVID-19 (Figure 7).

To our knowledge, this is the first study to demonstrate evidence of bacterial toxins including EAA, and the presence of circulating bacteriome in patients with COVID-19 pneumonia. We also showed the association of high level of EAA and the severity of COVID-19 pneumonia. Both the type of bateria and the presence of $\mathrm{BG}$ in the serum suggest that the gut is the source.

Our study had several limitations. First, our 16s RNA gene amplification technique could not demonstrate the absolute number of bacterial DNA. Therefore, we could not correlate the burden of circulating bacterial DNA to the severity of the patients. However, our study aimed to be a starting point for future investigation. Second, our study did not include respiratory tract or gastrointestinal specimens, so we cannot completely establish the source of bacterial products in our patients. Future study should explore the effect of organ crosstalk between the lung and the intestine during COVID-19 infection.

\section{Conclusion}


High levels of endotoxin activity and bacterial DNA can be found in the blood of patients with COVID-19 pneumonia which may reflect loss of epithelial barrier function. This previously unrecognized mechanism of hyperinflammation and organ failure in COVID-19 warrants further study.

\section{Contributors}

PS, WK, and NS were responsible for study concept and design. PS, WK, NS, TP, AC, SP, PP, SC, VS, NW, SK, OP, TT, NL, VP, NP, TS, RS, ST, KT, NLu, AL, TSri, TTa, UT, CC, KP, KTu, SE, JK, and NS were responsible for the acquisition, analysis, or interpretation of data. PS, WK and NS were responsible for drafting the manuscript. PS, WK and NS were responsible for statistical analysis. All authors had full access to all the data in the study and take responsibility for the integrity of the data and the accuracy of the data analysis All authors interpreted the findings, contributed to writing the manuscript, and approved the final version for publication.

\section{Declaration of interests}

Toray Industries provided endotoxin activity assay kits for use in this study. The company had no influence on the study design or analysis or on the comment of this article. None of the other authors have any disclosures.

\section{Acknowledgments}

We would like to thank the staff, fellows, nurses, and research coordinators from the Excellence Center for Critical Care Nephrology (EC-CCN) and Emerging Infectious Disease (EID) unit, Faculty of Medicine, Chulalongkorn University. We also thank Miss Pimnara Peerawaranun for statistical analysis and Miss Sasipha Tachaboon, MSc medical technologist, for laboratory procedures.

\section{Funding}

The investigator-initiated study was funded by the Excellence Center for Critical Care Nephrology, King Chulalongkorn Memorial Hospital. 
medRxiv preprint doi: https://doi.org/10.1101/2020.05.29.20109785; this version posted June 2, 2020. The copyright holder for this preprint (which was not certified by peer review) is the author/funder, who has granted medRxiv a license to display the preprint in perpetuity.

All rights reserved. No reuse allowed without permission.

\section{REFERENCES}

1. Bhatraju PK, Ghassemieh BJ, Nichols M, Kim R, Jerome KR, Nalla AK, Greninger AL, Pipavath S, Wurfel MM, Evans L, Kritek PA, West TE, Luks A, Gerbino A, Dale CR, Goldman JD, O'Mahony S, Mikacenic C, (2020) Covid-19 in Critically Ill Patients in the Seattle Region - Case Series. N Engl J Med

2. Singer M, Deutschman CS, Seymour CW, Shankar-Hari M, Annane D, Bauer M, Bellomo R, Bernard GR, Chiche JD, Coopersmith CM, Hotchkiss RS, Levy MM, Marshall JC, Martin GS, Opal SM, Rubenfeld GD, van der Poll T, Vincent JL, Angus DC, (2016) The Third International Consensus Definitions for Sepsis and Septic Shock (Sepsis-3). JAMA 315: 801-810

3. Zhou F, Yu T, Du R, Fan G, Liu Y, Liu Z, Xiang J, Wang Y, Song B, Gu X, Guan L, Wei Y, Li H, Wu X, Xu J, Tu S, Zhang Y, Chen H, Cao B, (2020) Clinical course and risk factors for mortality of adult inpatients with COVID-19 in Wuhan, China: a retrospective cohort study. Lancet 395: 1054-1062

4. Huang C, Wang Y, Li X, Ren L, Zhao J, Hu Y, Zhang L, Fan G, Xu J, Gu X, Cheng Z, Yu T, Xia J, Wei Y, Wu W, Xie X, Yin W, Li H, Liu M, Xiao Y, Gao H, Guo L, Xie J, Wang G, Jiang R, Gao Z, Jin Q, Wang J, Cao B, (2020) Clinical features of patients infected with 2019 novel coronavirus in Wuhan, China. Lancet 395: 497-506

5. Guan WJ, Ni ZY, Hu Y, Liang WH, Ou CQ, He JX, Liu L, Shan H, Lei CL, Hui DSC, Du B, Li LJ, Zeng G, Yuen KY, Chen RC, Tang CL, Wang T, Chen PY, Xiang J, Li SY, Wang JL, Liang ZJ, Peng YX, Wei L, Liu Y, Hu YH, Peng P, Wang JM, Liu JY, Chen Z, Li G, Zheng ZJ, Qiu SQ, Luo J, Ye CJ, Zhu SY, Zhong NS, China Medical Treatment Expert Group for C, (2020) Clinical Characteristics of Coronavirus Disease 2019 in China. N Engl J Med

6. Alhazzani W, Møller MH, Arabi YM, Loeb M, Gong MN, Fan E, Oczkowski S, Levy MM, Derde L, Dzierba A, Du B, Aboodi M, Wunsch H, Cecconi M, Koh Y, Chertow DS, Maitland K, Alshamsi F, Belley-Cote E, Greco M, Laundy M, Morgan JS, Kesecioglu J, McGeer A, Mermel L, Mammen MJ, Alexander PE, Arrington A, Centofanti J, Citerio G, Baw B, Memish ZA, Hammond N, Hayden FG, Evans L, A. R, (2020) Surviving Sepsis Campaign: Guidelines on the Management of Critically Ill Adults with Coronavirus Disease 2019 (COVID-19). ESICM

7. Luo S, Zhang X, Xu H, (2020) Don't Overlook Digestive Symptoms in Patients With 2019 Novel Coronavirus Disease (COVID-19). Clin Gastroenterol Hepatol 
medRxiv preprint doi: https://doi.org/10.1101/2020.05.29.20109785; this version posted June 2, 2020. The copyright holder for this preprint (which was not certified by peer review) is the author/funder, who has granted medRxiv a license to display the preprint in perpetuity.

All rights reserved. No reuse allowed without permission.

8. Zhang H, Kang Z, Gong H, Xu D, Wang J, Li Z, Cui X, Xiao J, Meng T, Zhou W, Liu J, Xu H, (2020)

The digestive system is a potential route of 2019-nCov infection: a bioinformatics analysis based on single-cell transcriptomes. bioRxiv

9. Opal SM, (2007) The host response to endotoxin, antilipopolysaccharide strategies, and the management of severe sepsis. Int J Med Microbiol 297: 365-377

10. Munford RS, (2008) Sensing gram-negative bacterial lipopolysaccharides: a human disease determinant? Infect Immun 76: 454-465

11. Danner RL, Elin RJ, Hosseini JM, Wesley RA, Reilly JM, Parillo JE, (1991) Endotoxemia in human septic shock. Chest 99: 169-175

12. Leelahavanichkul A, Worasilchai N, Wannalerdsakun S, Jutivorakool K, Somparn P, Issara-Amphorn J, Tachaboon S, Srisawat N, Finkelman M, Chindamporn A, (2016) Gastrointestinal Leakage Detected by Serum (1-->3)-beta-D-Glucan in Mouse Models and a Pilot Study in Patients with Sepsis. Shock 46: $506-518$

13. von Elm E, Altman DG, Egger M, Pocock SJ, Gotzsche PC, Vandenbroucke JP, Initiative S, (2007) The Strengthening the Reporting of Observational Studies in Epidemiology (STROBE) statement: guidelines for reporting observational studies. Ann Intern Med 147: 573-577

14. (2012) KDIGO Clinical Practice Guideline for Acute Kidney Injury. Kidney Int 2: 1-138

15. Romaschin AD, Harris DM, Ribeiro MB, Paice J, Foster DM, Walker PM, Marshall JC, (1998) A rapid assay of endotoxin in whole blood using autologous neutrophil dependent chemiluminescence. J Immunol Methods 212: 169-185

16. Worasilchai N, Leelahavanichkul A, Kanjanabuch T, Thongbor N, Lorvinitnun P, Sukhontasing K, Finkelman M, Chindamporn A, (2015) (1-->3)-beta-D-glucan and galactomannan testing for the diagnosis of fungal peritonitis in peritoneal dialysis patients, a pilot study. Med Mycol 53: 338-346

17. Wu L, Wen C, Qin Y, Yin H, Tu Q, Van Nostrand JD, Yuan T, Yuan M, Deng Y, Zhou J, (2015) Phasing amplicon sequencing on Illumina Miseq for robust environmental microbial community analysis. BMC Microbiol 15: 125

18. Bolyen E, Rideout JR, Dillon MR, Bokulich NA, Abnet C, Al-Ghalith GA, Alexander H, Alm EJ, Arumugam M, Asnicar F (2018) QIIME 2: Reproducible, interactive, scalable, and extensible microbiome data science. In: Editor (ed)^(eds) Book QIIME 2: Reproducible, interactive, scalable, and extensible microbiome data science. PeerJ Preprints, City, pp. 
medRxiv preprint doi: https://doi.org/10.1101/2020.05.29.20109785; this version posted June 2, 2020. The copyright holder for this preprint (which was not certified by peer review) is the author/funder, who has granted medRxiv a license to display the preprint in perpetuity.

All rights reserved. No reuse allowed without permission.

19. Rognes T, Flouri T, Nichols B, Quince C, Mahé F, (2016) VSEARCH: a versatile open source tool for metagenomics. PeerJ 4: e2584

20. Edgar RC, Haas BJ, Clemente JC, Quince C, Knight R, (2011) UCHIME improves sensitivity and speed of chimera detection. Bioinformatics 27: 2194-2200

21. DeSantis TZ, Hugenholtz P, Larsen N, Rojas M, Brodie EL, Keller K, Huber T, Dalevi D, Hu P, Andersen GL, (2006) Greengenes, a chimera-checked 16S rRNA gene database and workbench compatible with ARB. Appl Environ Microbiol 72: 5069-5072

22. Segata N, Izard J, Waldron L, Gevers D, Miropolsky L, Garrett WS, Huttenhower C, (2011) Metagenomic biomarker discovery and explanation. Genome biology 12: R60

23. Koch RM, Diavatopoulos DA, Ferwerda G, Pickkers P, de Jonge MI, Kox M, (2018) The endotoxininduced pulmonary inflammatory response is enhanced during the acute phase of influenza infection. Intensive Care Med Exp 6: 15

24. Lin E, Lowry SF, (1998) The Human Response to Endotoxin. Sepsis: 255-262

25. Ruhnke M, Bohme A, Buchheidt D, Cornely O, Donhuijsen K, Einsele H, Enzensberger R, Hebart H, Heussel CP, Horger M, Hof H, Karthaus M, Kruger W, Maschmeyer G, Penack O, Ritter J, Schwartz S, Infectious Diseases Working Party in H, Oncology of the German Society for H, Oncology, (2012) Diagnosis of invasive fungal infections in hematology and oncology--guidelines from the Infectious Diseases Working Party in Haematology and Oncology of the German Society for Haematology and Oncology (AGIHO). Ann Oncol 23: 823-833

26. Netea MG, Joosten LA, van der Meer JW, Kullberg BJ, van de Veerdonk FL, (2015) Immune defence against Candida fungal infections. Nat Rev Immunol 15: 630-642

27. Whittle E, Leonard MO, Harrison R, Gant TW, Tonge DP, (2018) Multi-Method Characterization of the Human Circulating Microbiome. Front Microbiol 9: 3266

28. Qiu J, Zhou H, Jing Y, Dong C, (2019) Association between blood microbiome and type 2 diabetes mellitus: A nested case-control study. J Clin Lab Anal 33: e22842

29. Li Q, Wang C, Tang C, Zhao X, He Q, Li J, (2018) Identification and Characterization of Blood and Neutrophil-Associated Microbiomes in Patients with Severe Acute Pancreatitis Using Next-Generation Sequencing. Front Cell Infect Microbiol 8: 5

30. Sato J, Kanazawa A, Ikeda F, Yoshihara T, Goto H, Abe H, Komiya K, Kawaguchi M, Shimizu T, Ogihara T, Tamura Y, Sakurai Y, Yamamoto R, Mita T, Fujitani Y, Fukuda H, Nomoto K, Takahashi 
medRxiv preprint doi: https://doi.org/10.1101/2020.05.29.20109785; this version posted June 2, 2020. The copyright holder for this preprint (which was not certified by peer review) is the author/funder, who has granted medRxiv a license to display the preprint in perpetuity. All rights reserved. No reuse allowed without permission.

T, Asahara T, Hirose T, Nagata S, Yamashiro Y, Watada H, (2014) Gut dysbiosis and detection of "live gut bacteria" in blood of Japanese patients with type 2 diabetes. Diabetes Care 37: 2343-2350

31. Panaiotov S, Filevski G, Equestre M, Nikolova E, Kalfin R, (2018) Cultural Isolation and Characteristics of the Blood Microbiome of Healthy Individuals. Advances in Microbiology: 406-421

32. Gosiewski T, Ludwig-Galezowska AH, Huminska K, Sroka-Oleksiak A, Radkowski P, Salamon D, Wojciechowicz J, Kus-Slowinska M, Bulanda M, Wolkow PP, (2017) Comprehensive detection and identification of bacterial DNA in the blood of patients with sepsis and healthy volunteers using nextgeneration sequencing method - the observation of DNAemia. Eur J Clin Microbiol Infect Dis 36: 329336

33. Wasiura J, Segal BH, Mullin KM, (2019) Cluster of Sphingomonas paucimobilis Bacteremias Linked to Diversion of Intravenous Hydromorphone. N Engl J Med 381: 584-585

34. Bhatt AS, Marty FM, Meyerson M, (2013) Bradyrhizobium enterica in cord colitis syndrome. N Engl J Med 369: 1867

35. Mishra D, Satpathy G, Wig N, Fazal F, Ahmed NH, Panda SK, (2020) Evaluation of 16S rRNA broad range PCR assay for microbial detection in serum specimens in sepsis patients. J Infect Public Health

36. Mehta P, McAuley DF, Brown M, Sanchez E, Tattersall RS, Manson JJ, Hlh Across Speciality Collaboration UK, (2020) COVID-19: consider cytokine storm syndromes and immunosuppression. Lancet 395: 1033-1034

37. Wong CK, Lam CW, Wu AK, Ip WK, Lee NL, Chan IH, Lit LC, Hui DS, Chan MH, Chung SS, Sung JJ, (2004) Plasma inflammatory cytokines and chemokines in severe acute respiratory syndrome. Clin Exp Immunol 136: 95-103

38. Mahallawi WH, Khabour OF, Zhang Q, Makhdoum HM, Suliman BA, (2018) MERS-CoV infection in humans is associated with a pro-inflammatory Th1 and Th17 cytokine profile. Cytokine 104: 8-13

39. Hanada S, Pirzadeh M, Carver KY, Deng JC, (2018) Respiratory Viral Infection-Induced Microbiome Alterations and Secondary Bacterial Pneumonia. Front Immunol 9: 2640

40. Jin X, Lian JS, Hu JH, Gao J, Zheng L, Zhang YM, Hao SR, Jia HY, Cai H, Zhang XL, Yu GD, Xu KJ, Wang XY, Gu JQ, Zhang SY, Ye CY, Jin CL, Lu YF, Yu X, Yu XP, Huang JR, Xu KL, Ni Q, Yu CB, Zhu B, Li YT, Liu J, Zhao H, Zhang X, Yu L, Guo YZ, Su JW, Tao JJ, Lang GJ, Wu XX, Wu WR, Qv TT, Xiang DR, Yi P, Shi D, Chen Y, Ren Y, Qiu YQ, Li LJ, Sheng J, Yang Y, (2020) 
medRxiv preprint doi: https://doi.org/10.1101/2020.05.29.20109785; this version posted June 2, 2020. The copyright holder for this preprint (which was not certified by peer review) is the author/funder, who has granted medRxiv a license to display the preprint in perpetuity.

All rights reserved. No reuse allowed without permission.

Epidemiological, clinical and virological characteristics of 74 cases of coronavirus-infected disease 2019 (COVID-19) with gastrointestinal symptoms. Gut

41. Lin L, Jiang X, Zhang Z, Huang S, Zhang Z, Fang Z, Gu Z, Gao L, Shi H, Mai L, Liu Y, Lin X, Lai R, Yan Z, Li X, Shan H, (2020) Gastrointestinal symptoms of 95 cases with SARS-CoV-2 infection. Gut 42. Ng SC, Tilg H, (2020) COVID-19 and the gastrointestinal tract: more than meets the eye. Gut: gutjnl2020-321195 
medRxiv preprint doi: https://doi.org/10.1101/2020.05.29.20109785; this version posted June 2, 2020. The copyright holder for this preprint (which was not certified by peer review) is the author/funder, who has granted medRxiv a license to display the preprint in perpetuity.

All rights reserved. No reuse allowed without permission.

Table 1. Clinical characteristics of COVID-19 pneumonia at enrollment

\begin{tabular}{|c|c|c|c|}
\hline Characteristic & $\begin{array}{c}\text { Total } \\
(\mathrm{N}=19)\end{array}$ & $\begin{array}{c}\text { EAA } \geq 0.6 \\
(\mathrm{~N}=8)\end{array}$ & $\begin{array}{c}\text { EAA }<0.6 \\
(\mathrm{~N}=11)\end{array}$ \\
\hline Age, years & $54(43,59)$ & $49(40,59)$ & $57(48,58)$ \\
\hline Male & $15(79 \%)$ & $6(75)$ & $9(82)$ \\
\hline APACHE II score & $\begin{array}{c}8(4,11) \\
\mathrm{N}=13\end{array}$ & $\begin{array}{l}9(5,10) \\
N=5\end{array}$ & $\begin{array}{c}7.5(4.0,11.5) \\
\mathrm{N}=8\end{array}$ \\
\hline SOFA score & $6(3,10)$ & $5(3,11)$ & $6(3.5,9)$ \\
\hline $\mathrm{PaO}_{2} / \mathrm{FiO}_{2}$ ratio at enrollment & $\begin{array}{c}233(186,261) \\
\mathrm{N}=13\end{array}$ & $\begin{array}{c}246(186,293) \\
N=5\end{array}$ & $\begin{array}{c}223(187,254) \\
N=8\end{array}$ \\
\hline \multicolumn{4}{|l|}{ Underlying disease } \\
\hline Hypertension & $6(32)$ & $1(13)$ & $5(45)$ \\
\hline Diabetes & $8(42)$ & $2(25)$ & $6(55)$ \\
\hline Chronic kidney disease & $2(11)$ & 0 & $2(18)$ \\
\hline $\begin{array}{l}\text { Time from onset of fever to } \\
\text { hospital admission (days) }\end{array}$ & $5(3,7)$ & $3.5(2,5)$ & $7(5,8)$ \\
\hline $\begin{array}{l}\text { Time from onset of fever to } 1^{\text {st }} \\
\text { EAA measurement (days) }\end{array}$ & $9(9,11)$ & $9(6,12.5)$ & $9(9,11)$ \\
\hline ICU admission (\%) & $13(68.4)$ & $6(75.0)$ & $7(63.6)$ \\
\hline Serum creatinine, $\mathrm{mg} / \mathrm{dL}$ & $0.90(0.80,1.16)$ & $0.82(0.69,1.07)$ & $0.91(0.86,1.28)$ \\
\hline EAA level & $0.57(0.47,0.86)$ & $0.86(0.80,0.90)$ & $0.48(0.42,0.57)$ \\
\hline Cycle threshold & $23.9(18.3,27.7)$ & $23.7(15.8,27.0)$ & $24.9(18.3,30.1)$ \\
\hline Ferritin & $872(638,2409)$ & $740(417,2047)$ & $1057(750,2771)$ \\
\hline CRP & $127(27.5,1457)$ & $38(27.5,130)$ & $137(70,175)$ \\
\hline Procalcitonin & $0.16(0.07,0.55)$ & $0.11(0.03,2.34)$ & $0.24(0.09,0.43)$ \\
\hline \multicolumn{4}{|l|}{ Treatment } \\
\hline Darunavir & $9(47)$ & $6(75)$ & $3(27)$ \\
\hline Ritonavir & $9(47)$ & $6(75)$ & $3(27)$ \\
\hline Favipiravir & $18(95)$ & $7(88)$ & $11(100)$ \\
\hline Antimalarial drug & $18(95)$ & $8(100)$ & $10(91)$ \\
\hline Azithromycin & $13(68)$ & $6(75)$ & $7(64)$ \\
\hline Corticosteroid & $4(21)$ & $3(38)$ & $1(9)$ \\
\hline Antibiotic & $13(68)$ & $5(63)$ & $8(73)$ \\
\hline
\end{tabular}

Data showed as counts (\%) or median (IQR)

APACHE II, Acute Physiology and Chronic Health Evaluation II; CRP, C-reactive protein; EAA, endotoxin activity assay; $\mathrm{FiO}_{2}$, fractional inspired oxygen; IL-6, interleukin-6; $\mathrm{PaO}_{2}$, partial pressure of arterial oxygen;

SOFA, sequential organ failure assessment.

Table 2. Outcomes at 28 days after enrollment

\begin{tabular}{|l|c|c|c|}
\hline \multicolumn{1}{|c|}{ Characteristic } & $\begin{array}{c}\text { Total } \\
(\mathbf{N = 1 9 )}\end{array}$ & $\begin{array}{c}\text { EAA } \geq \mathbf{0 . 6} \\
(\mathbf{N}=\mathbf{8})\end{array}$ & $\begin{array}{c}\text { EAA <0.6 } \\
\mathbf{( N = 1 1 )}\end{array}$ \\
\hline Subsequent bacterial infection & $5(26 \%)$ & $3(38 \%)$ & $2(18 \%)$ \\
\hline Total mechanical ventilation & $10(52.6)$ & $5(62.5)$ & $5(45.5)$ \\
\hline Successful extubation & $8 / 10(80 \%)$ & $4 / 5(80 \%)$ & $4 / 5(80 \%)$ \\
\hline Ventilator-free day (days) & $24(20,28)$ & $23.5(15,28)$ & $28(21.5,28)$ \\
\hline Vasopressor & $7(36.8)$ & $2(25.0)$ & $5(45.5)$ \\
\hline Prone position & $2(10.5)$ & $2(25.0)$ & 0 \\
\hline ECMO & $1(5.3)$ & $1(12.5)$ & 0 \\
\hline AKI & $8(42.1)$ & $2(25.0)$ & $6(54.5)$ \\
\hline RRT & $3(15.8)$ & $2(25.0)$ & $1(9.1)$ \\
\hline Mortality & 0 & 0 & 0 \\
\hline
\end{tabular}

Data showed as counts (\%) or median (IQR)

AKI, acute kidney injury; EAA, endotoxin activity assay; ECMO, extracorporeal membrane oxygenation; RRT, renal replacement therapy. 


\section{Figure legends}

Figure 1. Study cohort.

Figure 2a. EAA distribution of COVID-19 pneumonia.

Figure 2b. Serum BG distribution of COVID-19 pneumonia.

Figure 3. Dynamic bacterial community profiles on day 1 , day 3 , and day 7

Figure 4. Overall summary of dynamic bacterial community profiles in COVID-19 patients on day 1, 3, and 7 . Proteobacteria were observed to be the dominant bacterial phyla followed by Bacteroidetes, Actinobacteria and Firmicutes

Figure 5. Cytokine heat map on day 1, day 3, and day 7

Figure 6. Clinical outcomes in study cohort

Figure 7. Hypothetical pathogenesis of endotoxemia in COVID-19 pneumonia.

At early stage, SARS-CoV-2 primarily infects type 2 pneumocytes in the lungs and causes pneumonia which can progress to ARDS and induces susceptibility of secondary bacterial infection by impairing the pulmonary immune response. The virus can enter the bloodstream causing viremia targeting organs with high ACE2 expression including the gut. SARS-CoV-2 infection of enterocytes causes inflammatory response of gastrointestinal tract which results in alteration of the intestinal microenvironment including epithelial hyperpermeability, attenuated local immune system, and dysbiosis of the microbiome. The perturbations of the intestinal microenvironment allow the pathogenic bacteria from the gut lumen to translocate to the bloodstream Hence, we propose the sources of endotoxin to be majorly from the gut and minorly from the secondary bacterial infection of the lungs.

Abbreviations: COVID-19, the coronavirus disease 2019; SAR-CoV-2, severe acute respiratory syndrome coronavirus 2; ARDS, acute respiratory distress syndrome; ACE2, angiotensin converting enzyme 2; MOF, multiple organ failure 
Figure 1. Study cohort.

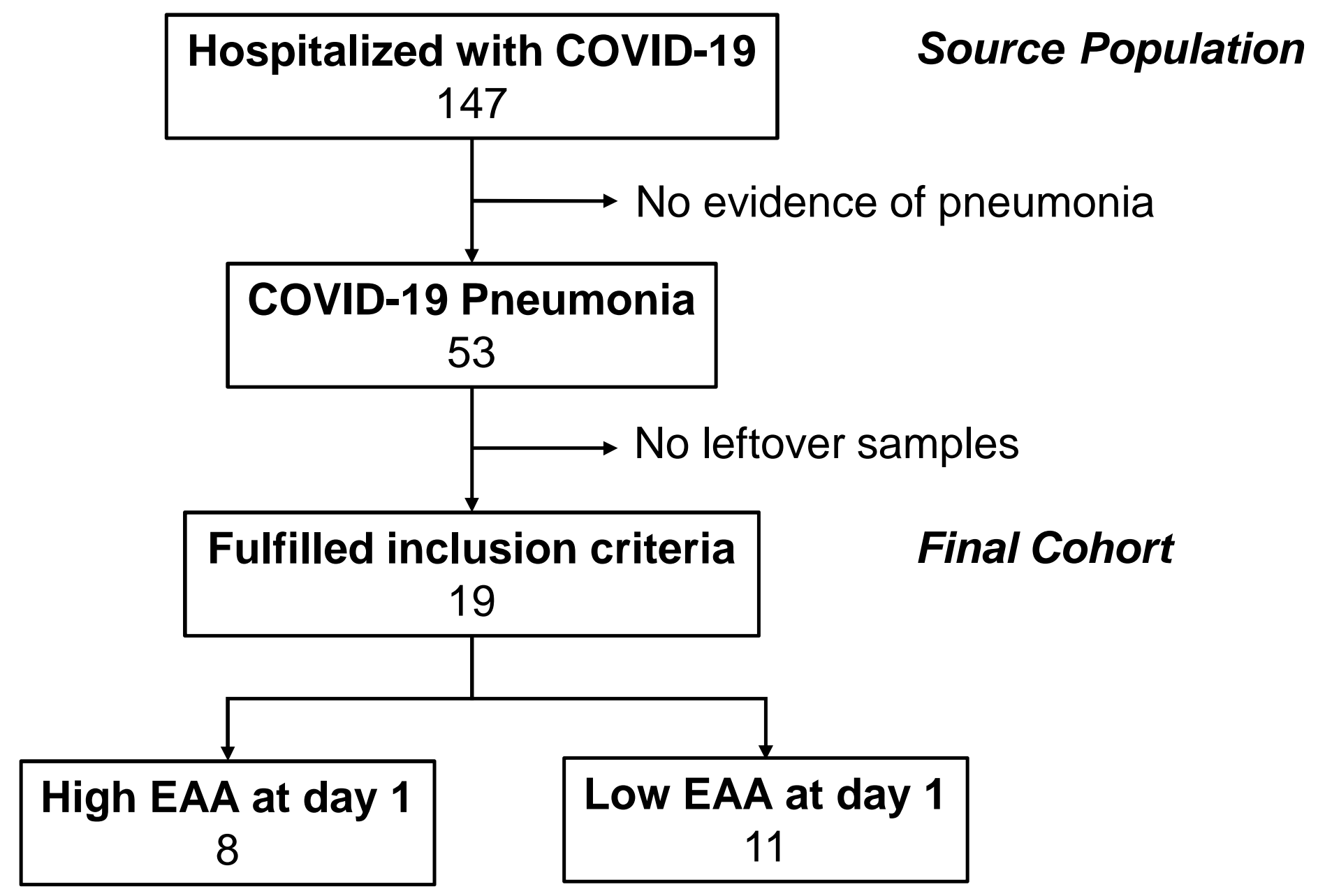


a. EAA distribution of COVID-19 pneumonia.
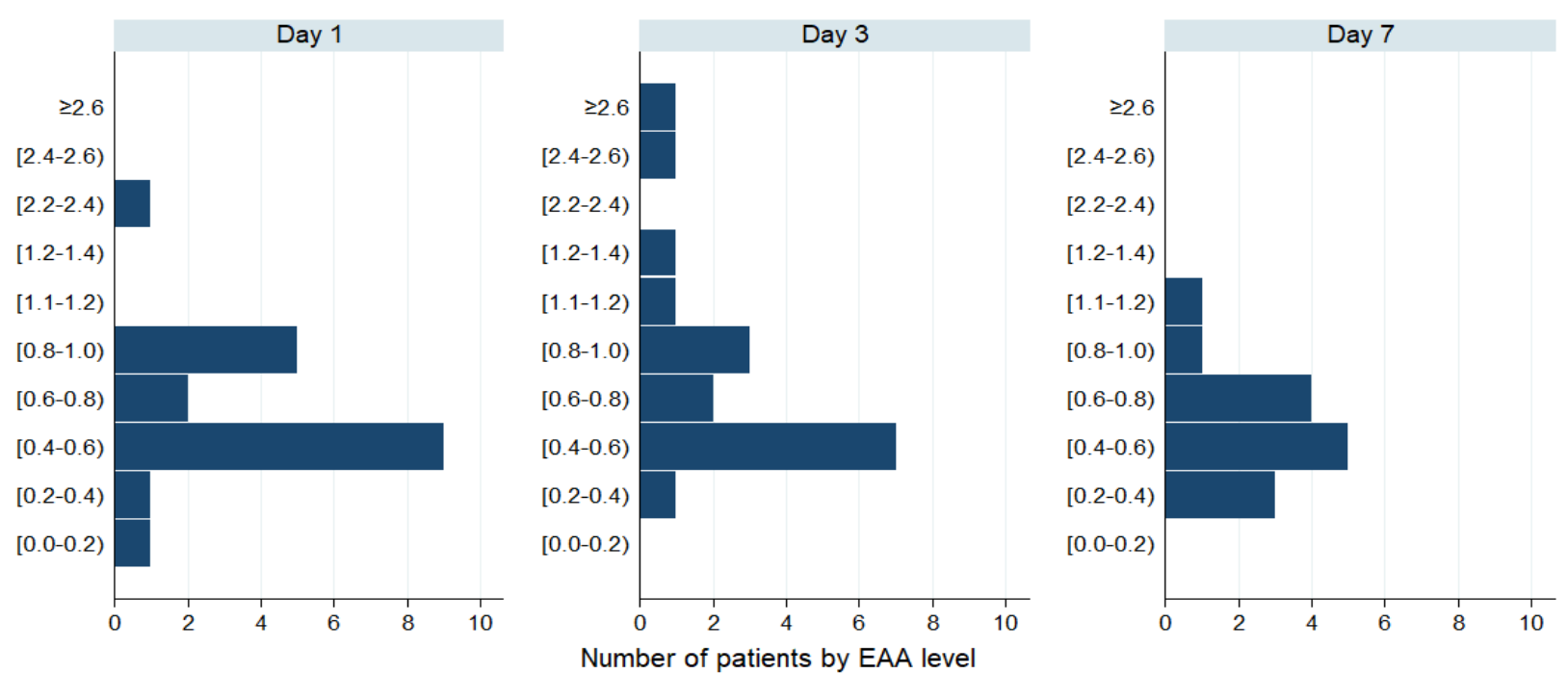

b. BG distribution of COVID-19 pneumonia.
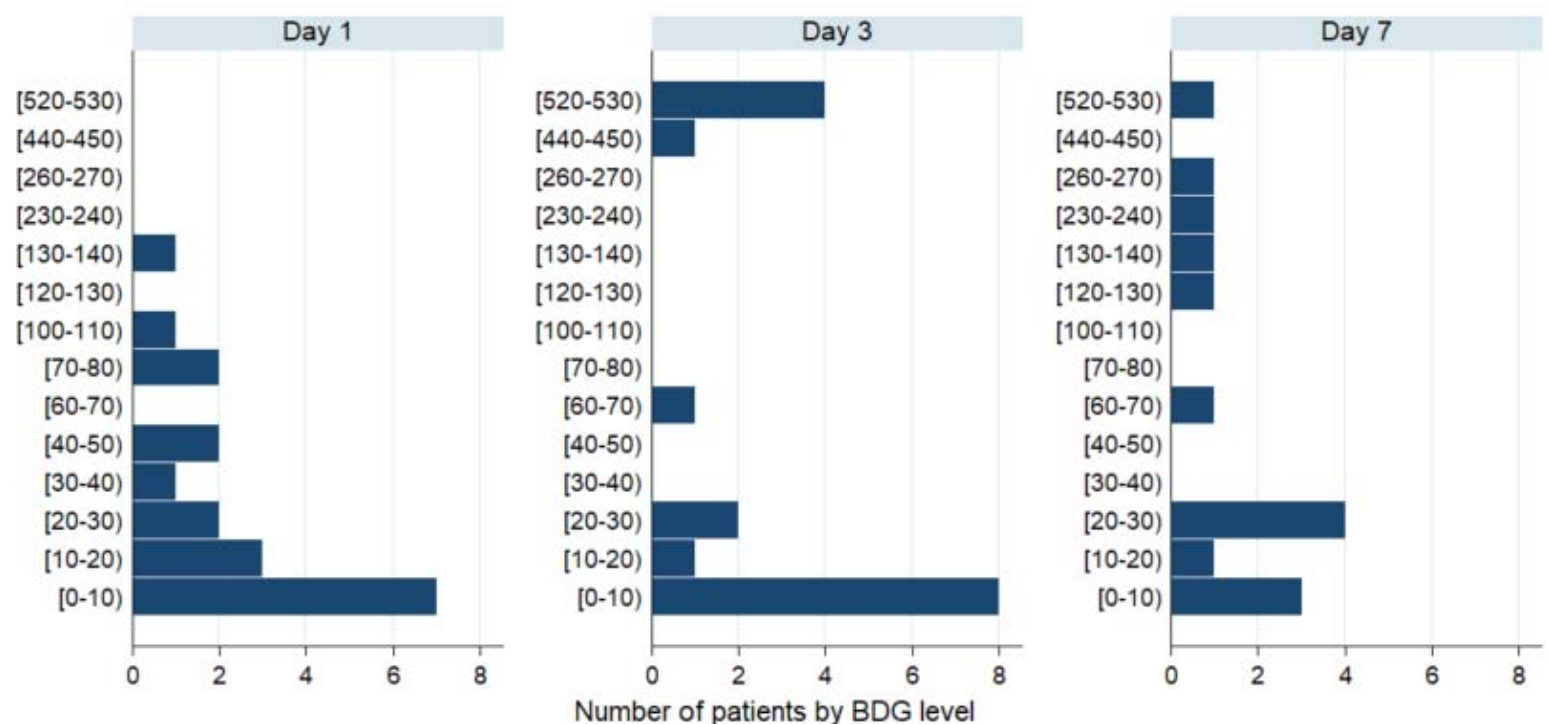
Dynamic bacterial community profiles at day 1 , day 3 , and day 7 .
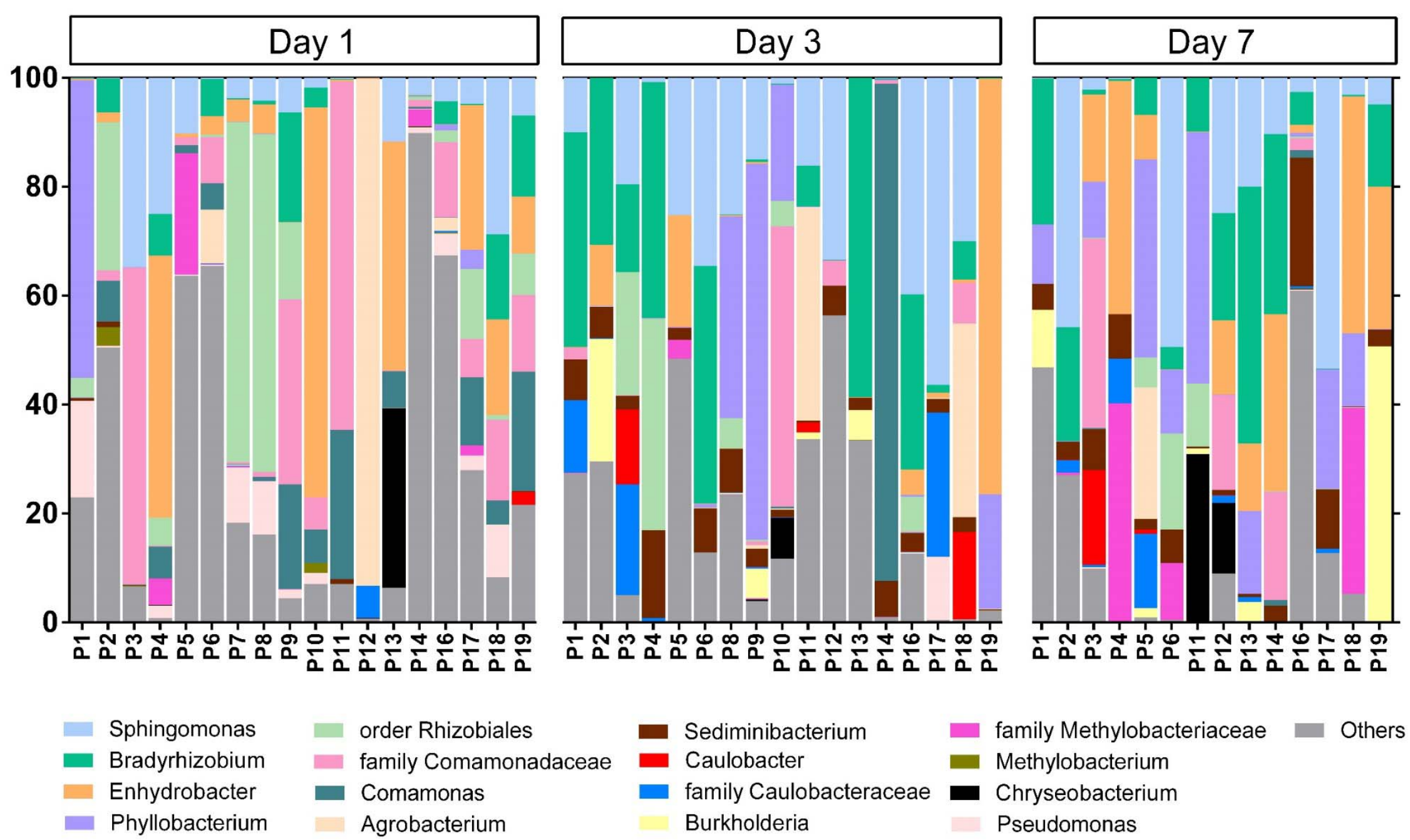
Sediminibacterium Caulobacter
family Caulobacteraceae Burkholderia
family Methylobacteriaceae Methylobacterium
- Chryseobacterium Pseudomonas


4. Overall summary of dynamic bacterial community profiles in COVID-19 patients $\mathrm{I}, 3$, and 7.

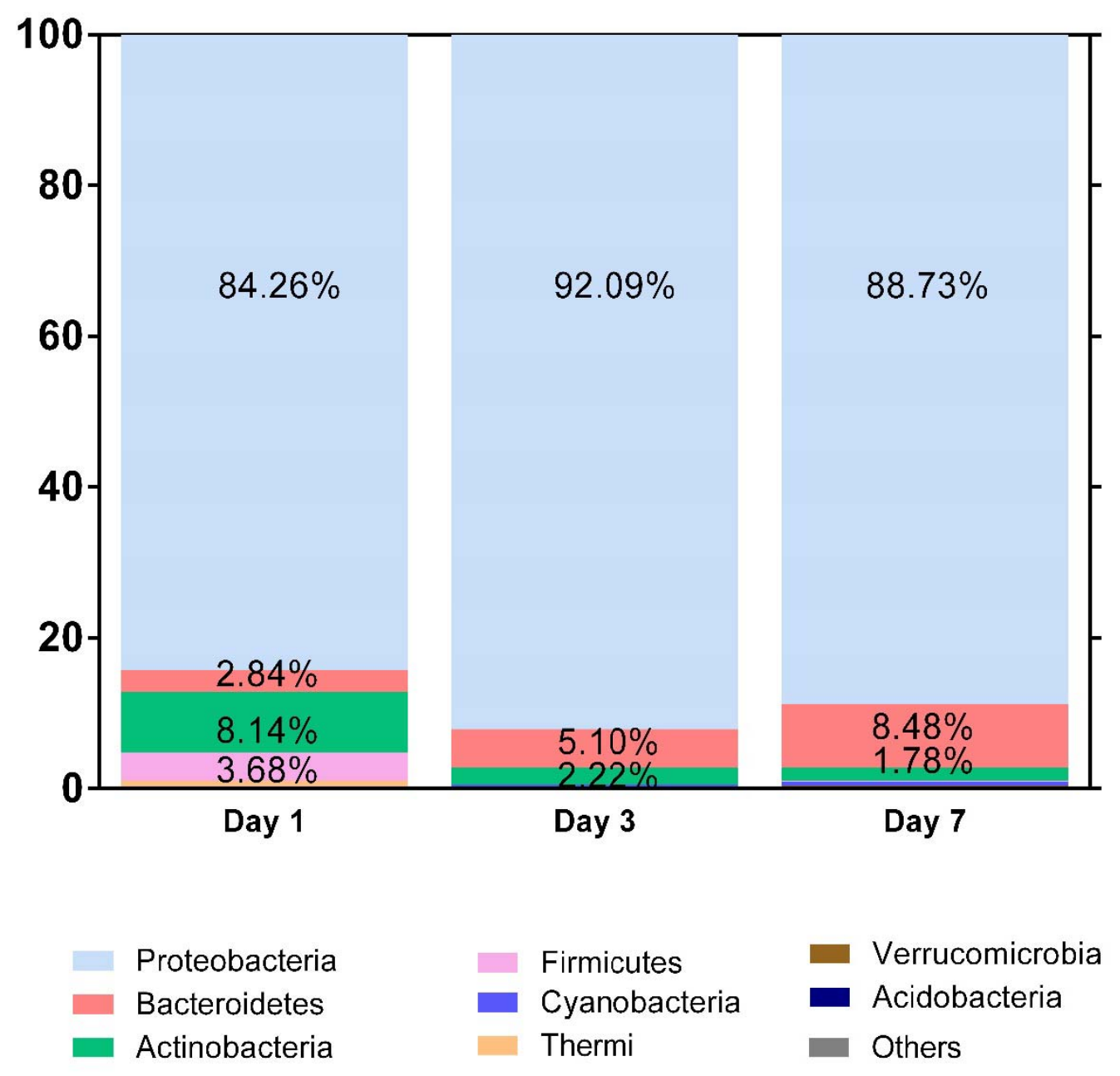


i. Cytokines heat map on day 1 , day 3 , and day 7 .

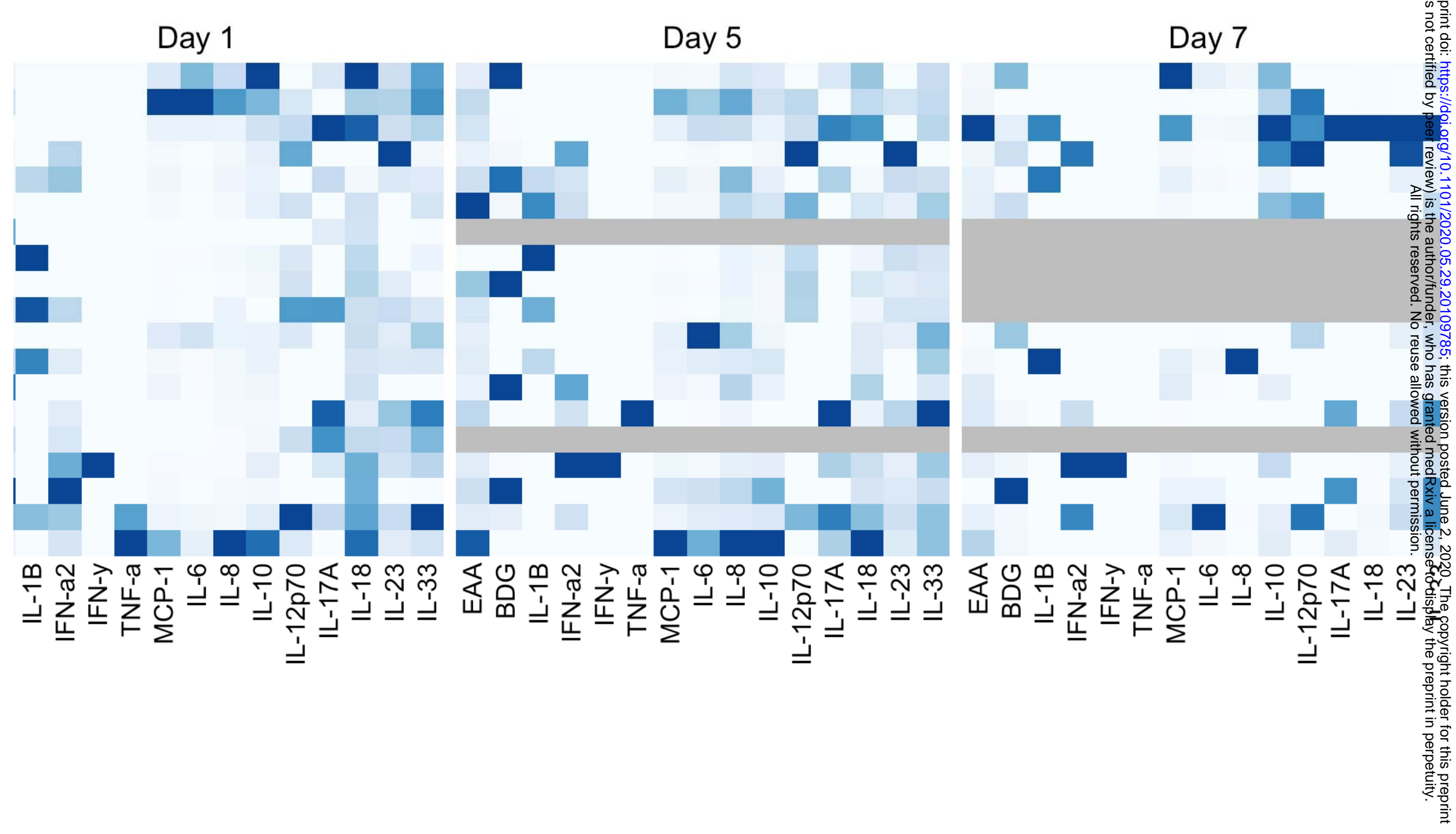


gure 7. Proposed mechanism of endotoxemia in COVID-19 pneumonia.

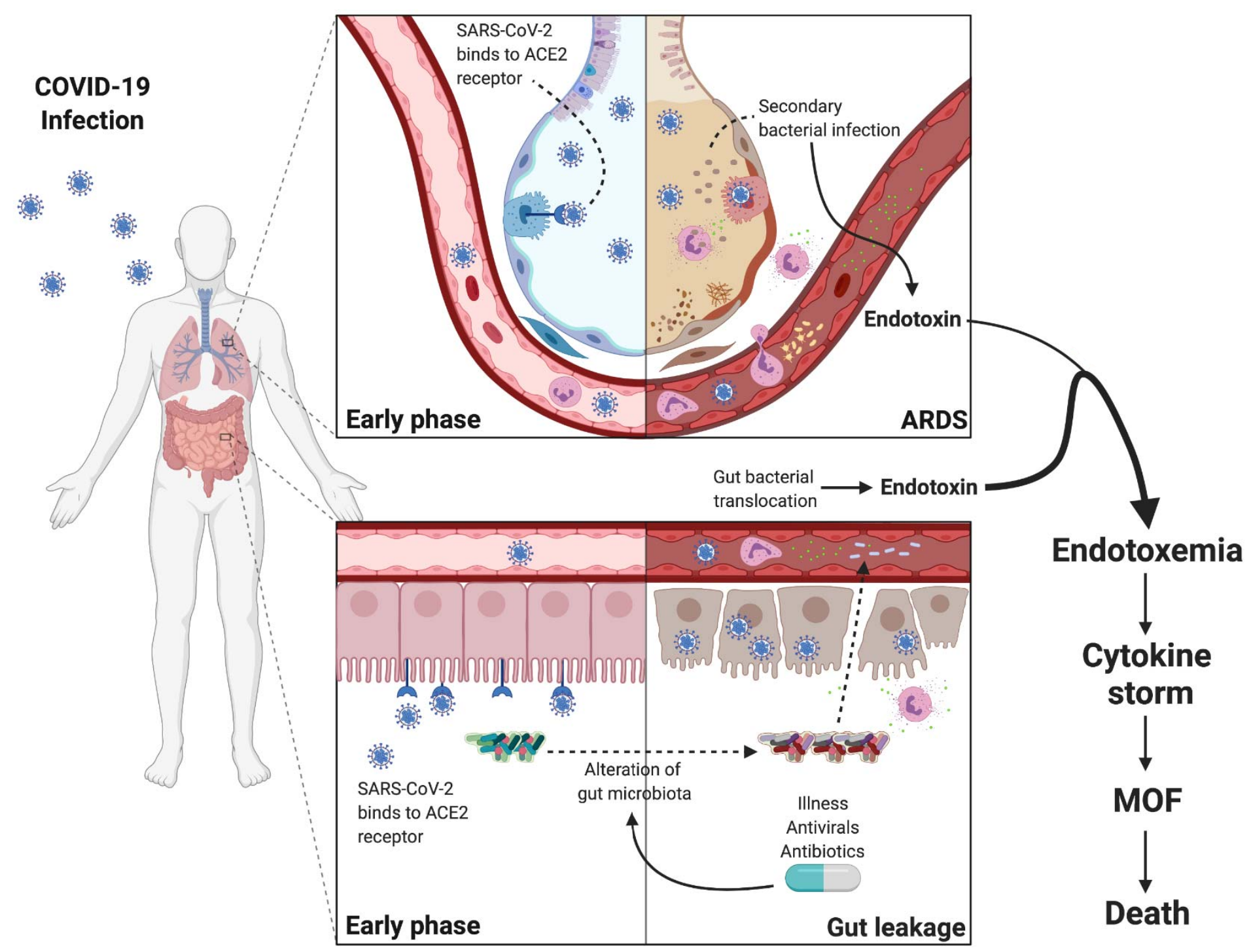


S1. Rarefaction curve of pass-filter reads obtained from each sample.

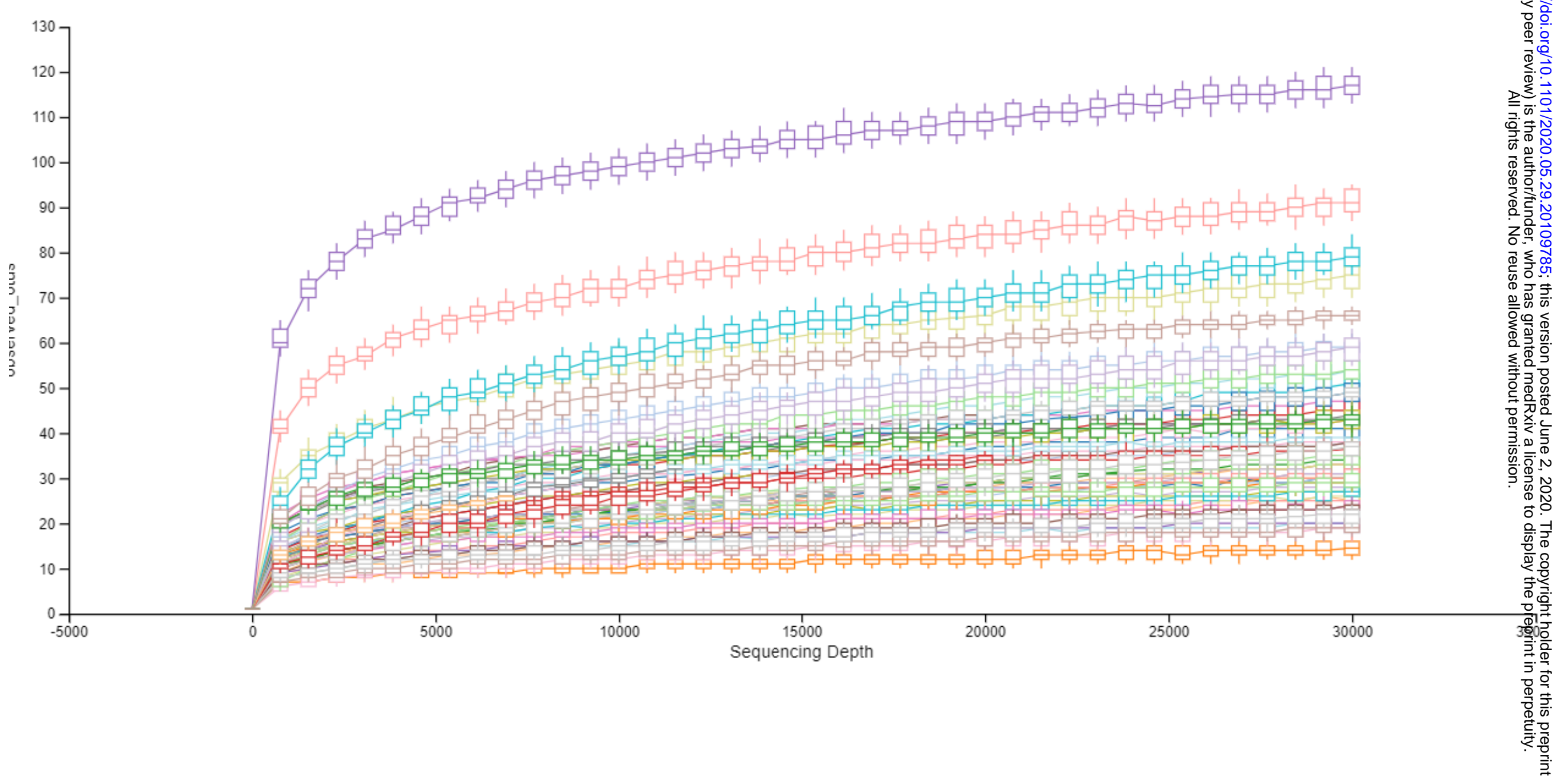


S2. Dynamic bacterial community profiles in COVID-19 patients on day 1,3 , and 7 .

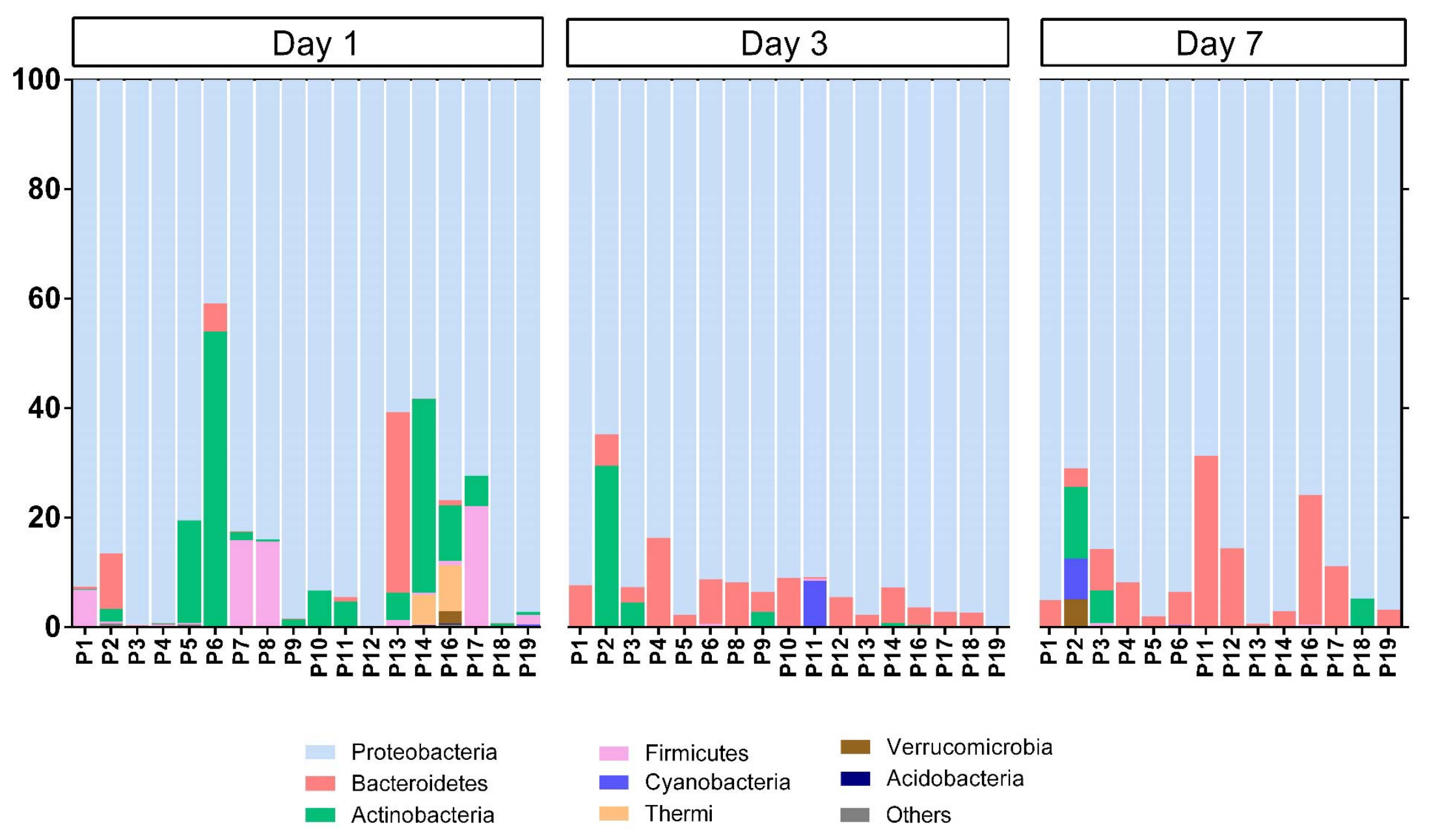


S3. Shannon diversity index $(A)$ and Chao1 richness $(B)$ representing alpha diversity srial community profiles in COVID-19 patients on day 1,3 , and 7.

A

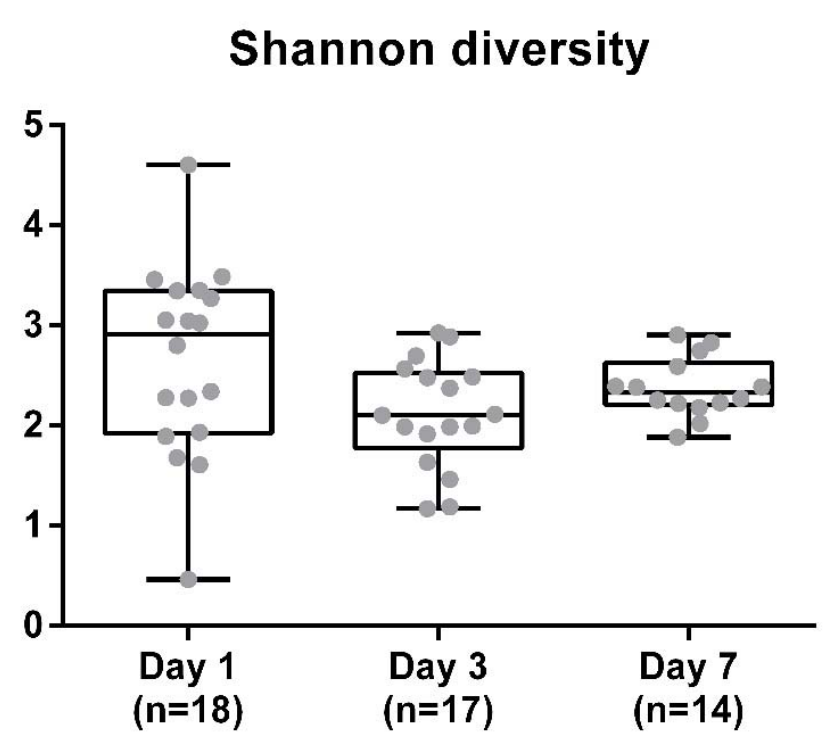

B

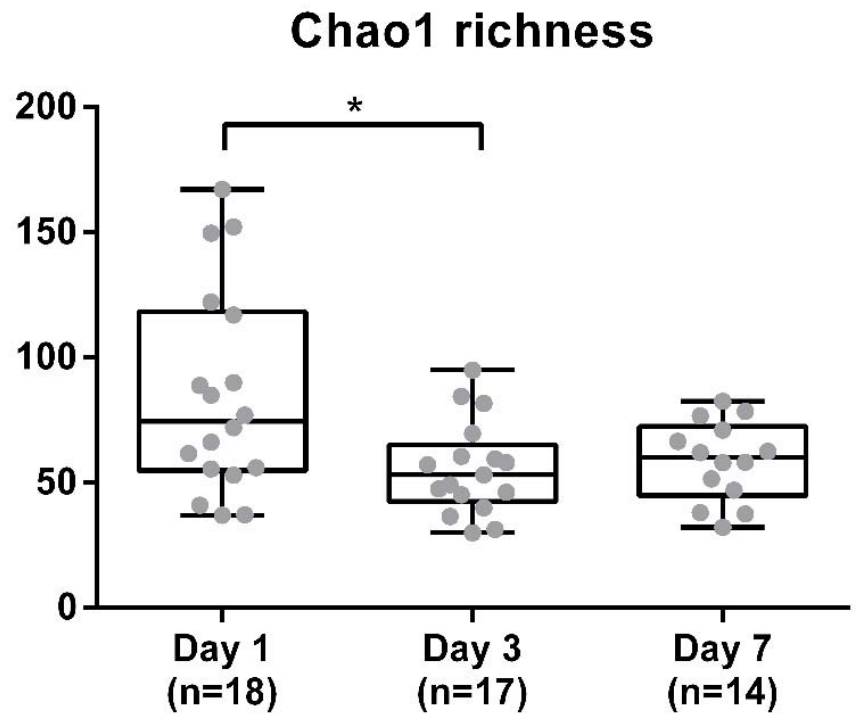


S4. Linear discriminant analysis effect size (LEfSe) analysis of bacteria on day 1 13.
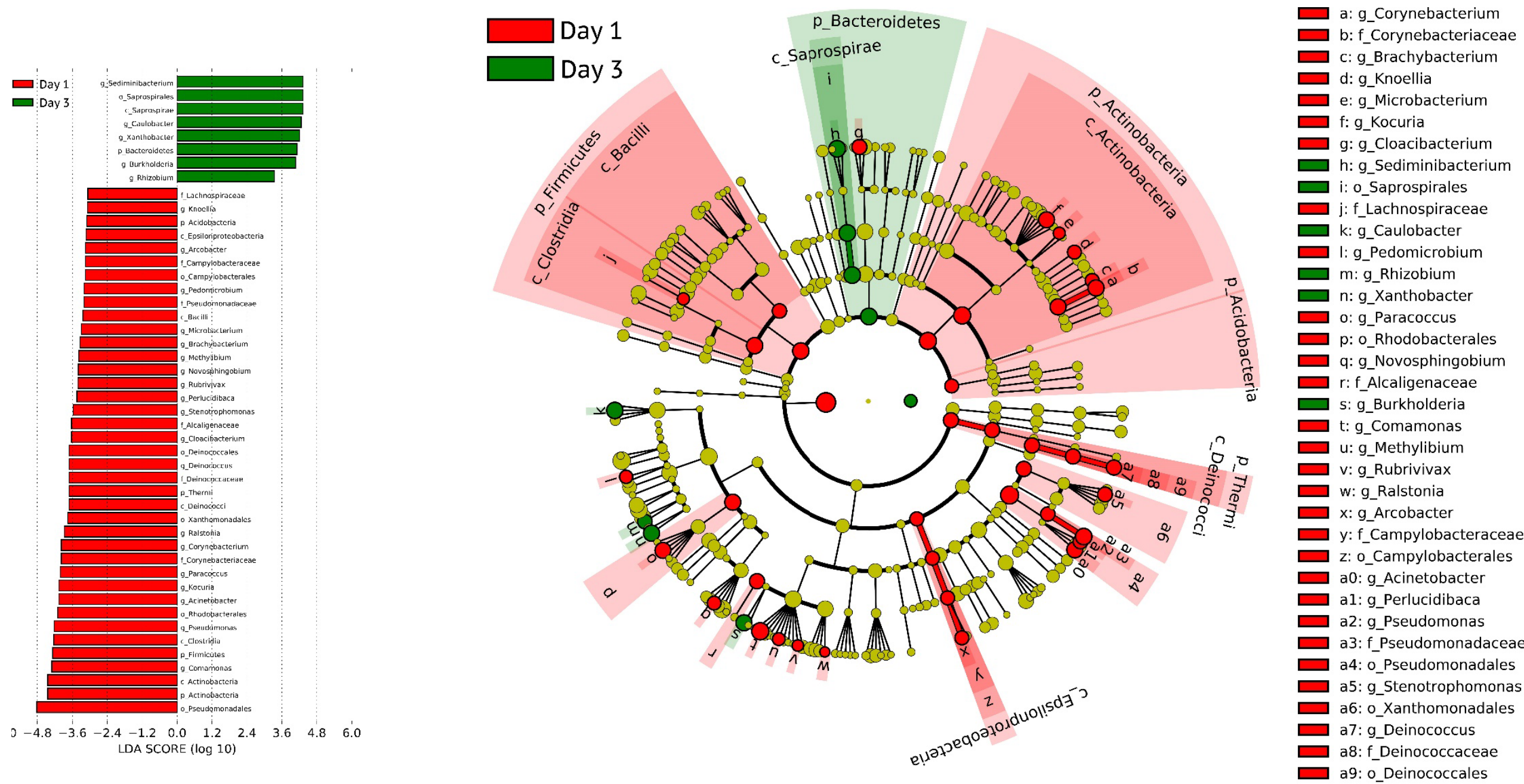
3 S5. Wilcoxon matched pairs test differential abundant of bacterial genera in each J-19 patients between day 1 and day 3 .
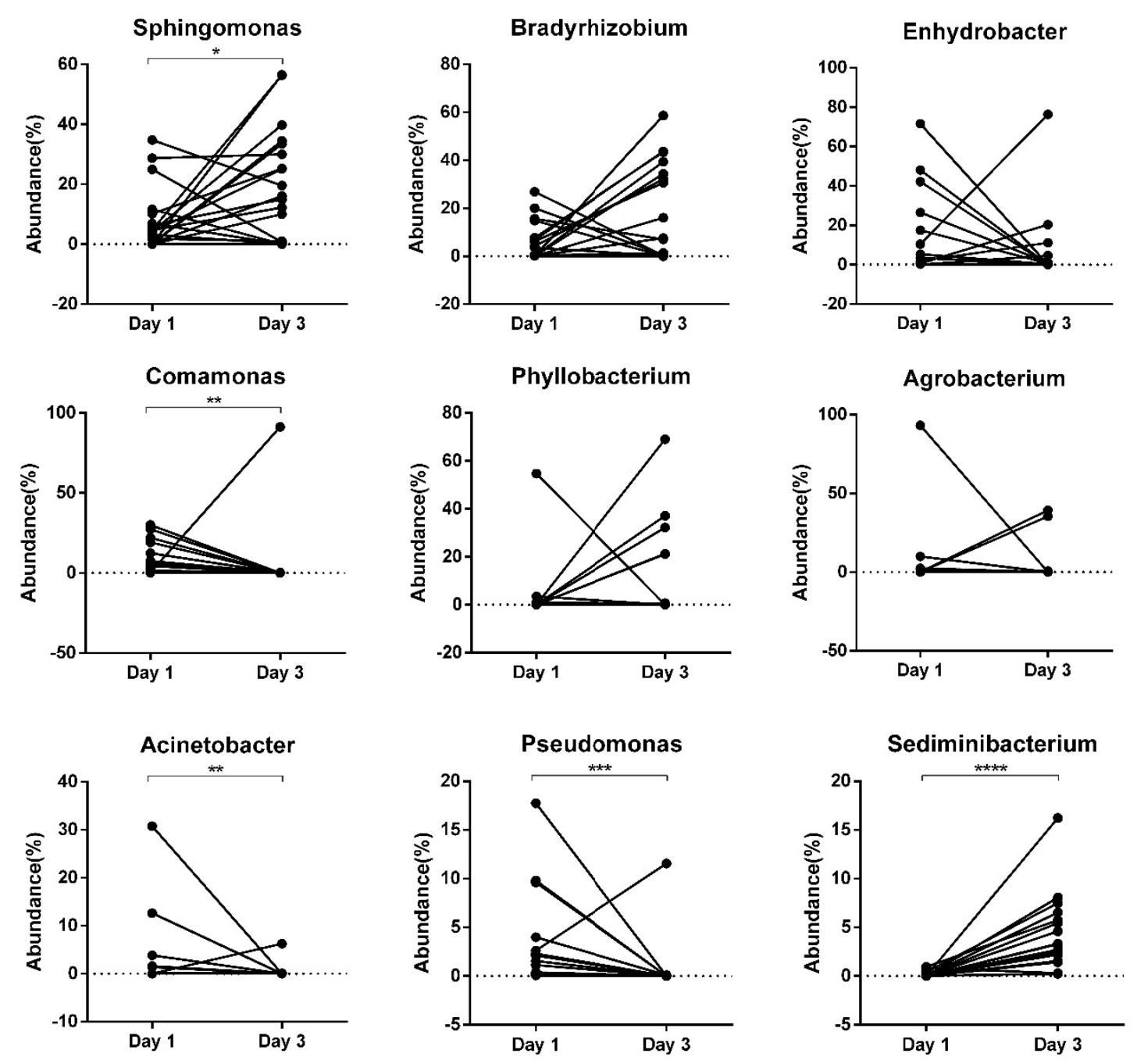